\title{
Faktor Penentu Amalan Kitar Semula Generasi Y Di Terengganu
}

\author{
Noor. H. Chekua, Ibrahim Mamata*, Mohd Yusri Ibrahim ${ }^{\mathrm{b}}$ \\ aInstitut Darul Iman, Universiti Sultan Zainal Abidin, 21030 Kuala Terengganu, Terengganu, Malaysia \\ ${ }^{b}$ Pusat Pengajian Asas dan Liberal, Universiti Malaysia Terengganu, 21030 Kuala Terengganu, Terengganu, Malaysia
}

*Corresponding author: mibrahim@unisza.edu.my

\begin{abstract}
Recycling campaign in Malaysia has failed because the practice of recycling among residents is still low. Thus, the Ministry of Housing and Local Government Malaysia has relaunched the campaign in 2001. Despite the high potential of recycling, only 10 per cent the amount of waste being recycled. This rate increased slowly, an increase of 5 percent over the past 12 years. This study aimed to investigate the relationship and the contribution of attitude towards recycle, environmental concerns and recycling practiced by Y generation in Terengganu. The respondents consisted of 338 students from seven institutions of higher education that represents Y generation for each district in the State. Questionnaire on environmental attitudes, environmental concerns and recycling practices was modified from previous studies and used as a research tool. Data were analyzed using SPSS 20. The findings showed that there was a significant relationship between the attitudes towards environment and practice of recycling $(r=0.80$, sig $=0.00)$ and environmental concerns with the practice of recycling $(r=0.82, \mathrm{sig}=0.00)$. The findings also discovered that the environmental attitudes and the concern for the environment have contributed $72.2 \%$ to the practice of recycling. This study suggests a number of strategies to increase recycling practices.
\end{abstract}

Keywords: Recycling practices, attitude towards recycling, environmental concerns, Y generation

\begin{abstract}
Abstrak
Kempen kitar semula di Malaysia telah gagal kerana amalan kitar semula dalam kalangan penduduk masih rendah. Dengan itu, Kementerian Perumahan dan Kerajaan Tempatan Malaysia telah melancarkan semula kempen tersebut pada 2001. Walaupun kitar semula berpotensi tinggi, hanya 10 peratus sahaja jumlah sisa yang sedang dikitar semula. Kadar ini meningkat dengan perlahan iaitu peningkatan sebanyak 5 peratus sejak 12 tahun yang lalu. Kajian ini bertujuan untuk mengkaji hubungan dan sumbangan sikap terhadap alam sekitar, keprihatinan alam sekitar dan amalan kitar semula yang diamalkan oleh generasi Y di Terengganu. Responden kajian terdiri daripada 338 orang pelajar daripada tujuh buah institusi pengajian tinggi yang mewakili generasi $Y$ bagi setiap daerah dalam Negeri Terengganu. Borang soal selidik kajian sikap terhadap alam sekitar, keprihatinan alam sekitar dan amalan kitar semula diubahsuai daripada kajian lepas dan digunakan sebagai alat kajian. Data dianalisis menggunakan perisian SPSS 20. Dapatan kajian menunjukkan bahawa wujud hubungan yang signifikan antara sikap alam sekitar dengan amalan kitar semula $(\mathrm{r}=0.80$, sig=0.00) dan keprihatinan alam sekitar dengan amalan kitar semula $(\mathrm{r}=0.82$, sig=0.00). Dapatan kajian juga menunjukkan keprihatinan alam sekitar dan sikap terhadap alam sekitar menyumbang sebanyak $72.2 \%$ kepada amalan kitar semula. Kajian ini mencadangkan beberapa strategi bagi meningkatkan amalan kitar semula.
\end{abstract}

Kata kunci: Amalan kitar semula, sikap terhadap kitar semula, keprihatinan alam sekitar, generasi Y.

\subsection{PENGENALAN}

Penggunaan yang berlebihan telah menjadi sinonim dengan kemusnahan alam sekitar di kebanyakan seluruh dunia. Dimensi perubahan ini boleh dijelaskan melalui fakta bahawa sejarah evolusi penggunaan dalam kalangan masyarakat mengatakan bahawa pengguna secara individu telah benar-benar memberi kesan dalam kemusnahan alam sekitar (Durning, 1992). Manusia berhadapan dengan empat situasi kritikal dalam memenuhi agenda kesinambungan tamadun manusia iaitu populasi yang semakin meningkat, pembangunan yang pesat, keharmonian sejagat dan alam sekitar (Holmes, 2006).

Penglibatan individu dalam pemuliharaan alam sekitar seperti kitar semula merupakan satu langkah besar dalam usaha pemuliharaan alam sekitar. Kegagalan dalam mendidik jiwa setiap individu bagi mengimbangi kemajuan dalam konteks kelestarian ekonomi, sosial dan alam sekitar telah menjadi satu kebimbangan yang perlu difikirkan bersama (Azizan, 2010).

Generasi Y dikatakan golongan yang celik teknologi, bermotivasi dan mereka membawa bersama mereka kepelbagaian budaya, tabiat dan tingkahlaku yang menghalang cara mereka bertindak, bekerja, berkomunikasi, dan beradaptasi dengan persekitaran, masyarakat dan cara pengurusan mereka (Johnson Controls Global WorkPlace Solutions (JCGWS, 2010).

Populasi generasi Y di seluruh dunia adalah sebanyak 1,723,911,077 bilion orang atau 25.47\% daripada jumlah keseluruhan penduduk dunia (JCGWS, 2010). Di Malaysia, populasi generasi Y adalah sebanyak 7,215,893 juta orang manakala di Terengganu generasi y adalah sebanyak 351,376 orang yang terdiri daripada 179,773 orang lelaki dan 171,603 orang perempuan (UPE, 2010).

Menurut JCGWS (2010), generasi Y menunjukkan aspirasi hijau melalui perjalanan kerja mereka, lokasi, pengangkutan, cara bekerja dan polisi hijau. generasi Y juga dikatakan sebagai hijau - kerja hijau - hidup hijau; yang mana generasi Y adalah tenaga kerja yang mesra alam. Generasi Y yang lebih berusia adalah jauh lebih hijau daripada generasi Y yang muda. 
Aspirasi sikap dan tanggungjawab terhadap alam sekitar daripada generasi Y adalah penting untuk menangani permasalahan tersebut kerana mereka memainkan peranan secara langsung dalam pengetahuan berasaskan penyelesaian kepada masalah alam sekitar pada masa hadapan (Bradley, Waliczek \& Zajicek, 1999; Eagles \& Demare, 1999).

Menurut Perbadanan Pengurusan Sisa Pepejal dan Pembersihan Awam (PPSPPA) (2011), kitar semula merupakan salah satu langkah terbaik untuk mendapatkan kesan yang positif untuk perlindungan alam sekitar kepada dunia yang sedang didiami ini. Kitar semula adalah penting bagi masyarakat dan alam semula jadi. Masyarakat khususnya pengguna perlu bertindak dengan pantas untuk mengamalkan kitar semula kerana jumlah bahan buangan atau sisa yang di buang semakin meningkat dari semasa ke semasa.

Pengurusan sisa pepejal merupakan masalah utama persekitaran yang dihadapi di Malaysia (World Bank, 1999). Sebanyak 21 peratus rungutan masyarakat kepada Jabatan Alam Sekitar Malaysia (JASM) adalah berhubung isu pencemaran udara dari tapak pelupusan dan pelupusan haram (JASM, 1998). KPKT telah mensasarkan kadar kitar semula di Malaysia sebanyak 25 peratus menjelang tahun 2015 (PPSPPA, 2011). Sehingga tahun 2011 kadar kitar semula hanya 5 peratus (PPSPPA, 2011). Kadar ini adalah jauh lebih rendah berbanding Jerman (74\%), Belgium (71\%), Austria (67\%) dan Belanda (66\%) (PPSPPA, 2011).

Penjanaan sisa pepejal terus meningkat sebanyak 33,000 tan metrik (Cheku, 2014). Ini menunjukkan bahawa peningkatan tersebut telah melebihi anggaran yang dijangka untuk tahun 2020 (Cheku, 2014). Selepas 12 tahun pelancaran semula kempen kitar semula hasilnya adalah masih sama iaitu kitar semula tidak menjadi amalan hidup penduduk Malaysia (Cheku, 2014). Walaupun kitar semula berpotensi tinggi, hanya 10 peratus sahaja jumlah sisa yang sedang dikitar semula (Cheku, 2014). Kadar ini meningkat dengan perlahan iaitu peningkatan sebanyak 5 peratus sejak 12 tahun yang lalu (Cheku, 2014). Kadar ini hanyalah separuh daripada sasaran kadar kitar semula kebangsaan secara purata iaitu sebanyak 20 peratus (PPSPPA, 2011).

Objektif kajian ini adalah untuk mengenalpasti hubungan antara faktor sikap alam sekitar dan keprihatinan alam sekitar dengan amalan kitar semula. Menentukan samada faktor sikap alam sekitar dan keprihatinan alam sekitar mempengaruhi amalan kitar semula dalam kalangan generasi Y Negeri Terengganu.

Seterusnya kajian ini dijalankan untuk menjawab persoalan-persoalan berikut;

i) Adakah sikap alam sekitar dan keprihatinan alam sekitar berhubungan secara positif dengan amalan kitar semula?

ii) Adakah sikap alam sekitar dan keprihatinan alam sekitar mempengaruhi amalan kitar semula dalam kalangan generasi Y?

Berdasarkan persoalan dan objektif kajian di atas, hipotesis kajian ini diperincikan seperti berikut:

i) Ha1: Sikap alam sekitar adalah berhubungan secara positif dengan amalan kitar semula dalam kalangan generasi Y.

ii) Ha2: Keprihatinan alam sekitar adalah berhubungan secara positif dengan amalan kitar semula dalam kalangan generasi $\mathrm{Y}$.

iii) Ha3: Sikap alam sekitar secara positif mempengaruhi amalan kitar semula dalam kalangan generasi Y.

iv) Ha4: Keprihatinan alam sekitar secara positif mempengaruhi amalan kitar semula dalam kalangan generasi Y.

Kajian ini membentuk satu kerangka konsep yang menjadikan faktor amalan kitar semula sebagai pemboleh ubah bersandar. Kerangka ini berdasarkan teori tingkahlaku terancang yang dibangunkan oleh Ajzen (1991). Teori ini mengatakan bahawa tingkahlaku dipengaruhi oleh sikap terhadap tingkahlaku, norma subjektif dan kawalan tingkahlaku (faktor luaran). Teori ini juga meramal dan menerangkan tingkahlaku manusia merupakan tingkahlaku yang spesifik (Ajzen, 1991). Berdasarkan teori dan literatur (Cheku, 2014; Sharifah Azizah, Laily \& Nurizan, 2005; Nik Abdul Rashid, 2009; Mohamad Fazli \& Yong, 2006) kerangka bagi kajian ini dirangka seperti Rajah 1 di bawah.

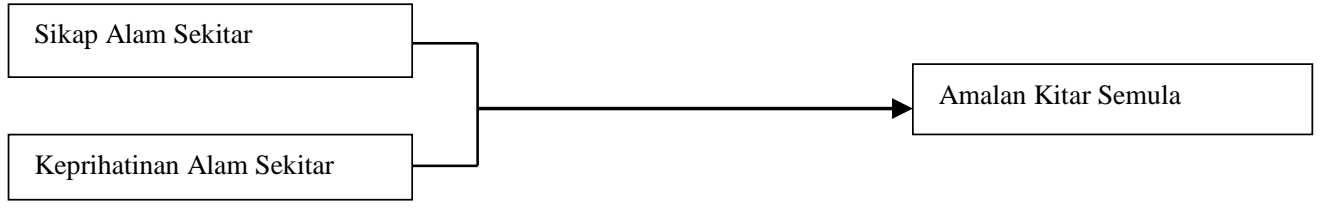

Rajah 1 Kerangka konseptual kajian amalan kitar semula

\subsection{SOROTAN LITERATUR}

Kitar semula merujuk kepada pengembalian sesuatu bahan atau produk kepada bentuk lain atau dalam erti mudah membawa maksud penukaran sisa buangan melalui penjanaan oleh aktiviti manusia kepada bahan lain yang boleh digunakan atau dimanafaat dalam penggunaan berbeza (Wilson 1981; Evison \& Read 2001; dan Robinson \& Read 2005).

Pengurusan sisa pepejal dan pembersihan awam yang cekap dan berkesan amat penting bagi memastikan kualiti hidup yang tinggi dan alam sekitar yang bersih, sihat dan selamat. Sehubungan dengan itu, Pelan Perancangan Strategik Nasional untuk Pengurusan Sisa Pepejal 2005 menggariskan pengurusan sisa pepejal hendaklah berteraskan kepada hirarki pengurusan sisa pepejal. Hirarki tersebut terdiri daripada elemen-elemen berikut yang disusun mengikut keutamaan iaitu pengurangan, guna semula, kitar semula, rawatan perantaraan dan pelupusan.

Kitar semula adalah salah satu mekanisma penting dalam pengurusan sisa pepejal (Rabinson, 1986). Pertubuhan Pelupusan Sisa Pepejal meramalkan bahawa jika separuh daripada sisa kertas dalam komposisi sisa pepejal dikitar semula, ia sama dengan mengekalkan 8 juta hektar hutan (Payam, 1995). Kitar semula dapat mengurangkan jumlah sisa dan mengurangkan ruang yang diperlukan untuk pelupusan sisa (Kazemi, 1996).

Kitar semula juga sangat penting kepada bandar di seluruh dunia dan manusia yang hidup di dalamnya (PPSPPA, 2011), antaranya meningkatkan jangka hayat tapak pelupusan. Selain itu juga, kebanyakkan kawasan tanah di negara kita didapati kurang sesuai untuk membina tapak pelupusan disebabkan sebahagian besar meliputi kawasan tadahan air (PPSPPA, 2011). Kitar semula dapat mengurangkan kos pelupusan melalui pengurangan aktiviti pengumpulan dan pengurangan keperluan tapak pelupusan yang baru. 
Kitar semula dapat mengurangkan belanjawan kewangan dengan menghasilkan produk daripada bahan mentah lebih tinggi kosnya berbanding di hasilkan daripada bahan-bahan kitar semula (PPSPPA, 2011). Kitar semula dapat menjimatkan pertukaran wang asing melalui pengurangan import bahan mentah dari luar negara (Latifah, 2011). Kitar semula boleh menangani pelepasan gas karbon dioksida ke udara yang menyumbang kepada pemanasan global kesan rumah hijau yang mempunyai kaitan dengan pencairan ais di kutub utara dan kutub selatan yang seterusnya membawa kepada peningkatan aras laut yang mengancam ekosistem pesisir pantai dan mendatangkan impak negatif kepada manusia (Abu Hanifah, Mohd Rafi \& Nik Mazlan, 2012).

Sikap sangat mempengaruhi tingkahlaku dan adalah penting untuk menilai sikap dalam setiap penyelidikan tingkahlaku pengguna (Ajzen \& Fishbein, 1980; Arcury \& Christianson, 1990; Bejou \& Thorne, 1991; Samuelson \& Biek, 1991; dan Follows \& Jobber, 2000). Nik Abdul Rashid (2009) mendefinisikan sikap alam sekitar sebagai kecenderungan untuk belajar bertindak balas secara konsisten dengan memihak atau tidak memihak kepada alam sekitar.

Sikap alam sekitar memainkan peranan penting dalam mempengaruhi dan mendorong tingkahlaku manusia terhadap alam sekitar (Ajzen \& Fishbein, 1980; Knapp, 1999). Individu yang bersikap positif terhadap alam sekitar akan mengaplikasikan sikap tersebut dalam kehidupan seharian (Ajzen \& Fishbein, 1980). Pendapat ini telah disokong dengan kajian yang telah dijalankan oleh (Mittelstaedt, Sanker \& VanderVeer, 1999; Daigle, Hrubes \& Ajzen, 2002).

Gill, Crosby dan Taylor (1986) berhujah bahawa terdapat hubungan yang signifikan antara sikap dan tingkahlaku apabila sikap dan tingkahlaku mengukur sesuatu yang khusus. Mereka melaporkan terdapat hubungan positif antara sikap dan tingkahlaku dalam pelbagai tindakan. Kajian Jamilah, Hasrina, Hamidah dan Juliana (2011) mendapati sikap orang awam terhadap isu alam sekitar adalah pada tahap yang masih rendah. Mereka juga mendapati amalan orang awam terhadap pemuliharaan alam sekitar di Pulau Pinang dan Kuala Lumpur berada pada tahap yang rendah.

Minton dan Rose (1997) mendefinisikan keprihatinan alam sekitar sebagai sikap umum ke arah memelihara alam sekitar. Hasil kajian Mohamad Fazli dan Yong (2006) mendapati bahawa majoriti responden mempunyai tahap keprihatinan yang tinggi terhadap masalah alam sekitar dan berpendapat bahawa pihak kerajaan, pihak pengeluar, pengiklanan dan sekolah harus memainkan peranan dalam usaha melindungi alam sekitar. Hasil kajian mereka juga mendapati majoriti responden menyatakan mereka marah dan berasa kecewa apabila memikirkan cara industri mencemarkan alam sekitar.

Keprihatinan alam sekitar mengkehendaki kita supaya sedar tentang cara kehidupan yang akan memberi kesan negatif kepada alam sekitar dan cuba mengubah sikap kepada sikap baru yang ingin mengekalkan dan menggalakkan keadaan alam sekitar yang berkualiti (Soon, 1988). Menurut Chan dan Lau (2000) keprihatinan terhadap ekologi dan ilmu pengetahuan adalah ramalan penting pengguna terhadap niat membeli produk hijau. Dengan menggunakan model persamaan struktur, Chan dan Lau (2000) menunjukkan bahawa hubungan positif yang kuat wujud di antara keprihatinan ekologi dan niat membeli produk hijau. Walau bagaimanapun Paco, Raposo dan Filho, (2009) menunjukkan penemuan yang bercanggah iaitu walaupun responden prihatin mengenai alam sekitar, tetapi mereka tidak mengaplikasikan keprihatinan mereka ke dalam tindakan dan mereka jarang mengambil bahagian dalam acara alam sekitar. Keprihatinan adalah lebih berkaitan dengan faktor-faktor ekonomi dan bukannya faktor-faktor alam sekitar.

Amalan kitar semula berkait rapat dengan sikap seseorang terhadap alam sekitar. Sikap sangat mempengaruhi tingkahlaku dan adalah penting untuk menilai sikap dalam setiap penyelidikan tingkahlaku pengguna (Ajzen \& Fishbein, 1980; Arcury \& Christianson, 1990; Bejou \& Thorne, 1991; Samuelson \& Biek, 1991; dan Follows \& Jobber, 2000).

\subsection{METODOLOGI KAJIAN}

Kajian ini menggunakan reka bentuk tinjauan secara rentasan dengan mengaplikasikan pendekatan kuantitatif. Populasi kajian adalah pelajar IPT di Terengganu yang terdiri daripada pelajar diploma, ijazah sarjana muda dan pasca siswazah. Skala Likert dari skala 1 hingga 5 telah digunakan untuk mengukur setiap item dalam borang soal selidik. Skala 1 sebagai sangat tidak setuju dan 5 sebagai sangat setuju.

Data kajian dikumpul menggunakan borang soal selidik yang diubahsuai daripada soal selidik yang telah digunakan dalam Malaysia dan kesemua pembolehubah berdimensi tunggal. Borang soal selidik mengandungi empat bahagian utama iaitu demografi responden, pembolehubah bersandar amalan kitar semula, sikap alam sekitar dan keprihatinan alam sekitar. Seramai 338 responden telah menjawab dengan sempurna borang soal selidik yang ditadbir secara peribadi mengikut formula penentuan saiz sampel yang dicadangkan oleh Krejcie dan Morgan (1970).

Kajian ini membuat persampelan di institusi pengajian tinggi Negeri Terengganu. Melibatkan senarai awal responden seramai 490 orang yang mana setiap satu institusi menyumbang pada kadar 3.06\% daripada jumlah keseluruhan responden. Pemilihan responden menggunakan teknik persampelan rawak berstrata dan saiz sampel ditentukan berdasarkan formula penentuan saiz sampel Krejcie dan Morgan (1971). Responden adalah terdiri daripada pelajar diploma, ijazah sarjana muda dan pelajar pasca siswazah yang berada dalam kategori generasi Y yang diguna pakai dalam kajian ini. Institusi pengajian tinggi dipilih adalah kerana populasi generasi Y banyak terdapat di institusi pengajian tinggi.

Alat kajian bagi pembolehubah amalan kitar semula diadaptasi daripada kajian McCarty dan Shrum (1994). Alat kajian ini telah digunakan oleh kajian Mohd Nasir, Rakmi, Theng, Zulina dan Muhamad, (2000), Sharifah Azizah, et. al., (2005), Webb, Mohr dan Harris, (2008), Lau, (2010) dan Saripah dan Mohd Shukri (2012).

Alat kajian bagi pembolehubah sikap alam sekitar diadaptasi daripada kajian Rahbar dan Nabsiah (2010). Alat kajian ini mengandungi 13 item dan dibangunkan oleh Bohlen, Schlegelmilch dan Diamantopoulos, (1993). Alat kajian ini juga telah digunakan dalam kajian Sharifah Azizah et. al., (2005) dan Nik Abdul Rashid (2009). Alat kajian bagi pembolehubah keprihatinan alam sekitar diadaptasi daripada kajian Mohamad Fazli dan Yong (2006). Alat kajian mengandungi 16 item dan dibangunkan oleh Antil dan Bennett (1979) dan juga telah digunakan dalam kajian Minton dan Rose (1997). 


\subsection{KEPUTUSAN}

Seramai 338 responden telah menjawab dan memulangkan borang soal selidik yang diedarkan. Bagi konstruk amalan kitar semula, kajian ini mengugurkan item aks1, aks2 dan aks3 dalam analisis CFA kerana nilai outer loading tidak sepadan. Bagi konstruk sikap terhadap alam sekitar, kajian ini mengugurkan item sks5 kerana nilai outer loading sangat rendah iaitu 0.136. Kajian ini juga menggugurkan item sks1, sks2 dan sks4 kerana apabila kajian ini menggugurkan item aks5 nilai outer loading bagi sks1, sks2 dan sks4 berkurang dan tidak sepadan dengan nilai yang ditetapkan. Kajian ini juga memadam item pas1, pas5 dan pas8 kerana nilai outer loading bagi pas1, pas5 dan pas8 menjadi rendah setelah item pas6, pas7 dan pas13 digugurkan. Item-item lain dikekalkan kerana nilai outer loading adalah mencapai nilai yang ditetapkan.Data kajian ini juga mendapati semua nilai Skewness dan Kurtosis bagi pembolehubah kajian berada dalam taburan normal $(\leq \pm 1)$.

Daripada 338 responden yang dianalisis, sebanyak 163 atau 48.2 peratus adalah responden lelaki manakala bakinya adalah responden perempuan. Seramai 239 orang responden berusia 19-22 tahun, manakala selebihnya berusia 23-29 tahun. Responden yang sedang mengikuti pengajian diploma sebanyak 115, ijazah sarjana muda 179, ijazah sarjana 35 dan ijazah kedoktoran seramai 9 orang.

Jadual 1 secara umumnya memaparkan responden di Terengganu melaksanakan amalan kitar semula pada tahap yang sederhana ( $\min =3.02, \mathrm{sp}=0.96)$. Tahap tinggi dalam skala ini bermaksud tingkahlaku diamalkan secara kerap. Tahap sederhana pula bermaksud tingkahlaku tersebut diamalkan sekali-sekala (McCarty \& Shrum, 1994; Saripah \& Mohd Shukri, 2012).

Jadual 1 Tahap amalan kitar semula

\begin{tabular}{llcccc}
\hline & \multicolumn{1}{c}{ Fungsi } & N & Min & SP & Tahap \\
\hline Aks4 & Saya kitar semula barangan plastik. & 338 & 3.09 & 0.93 & Sederhana \\
Aks5 & Saya kitar semula botol kaca. & 338 & 2.96 & 0.98 & Sederhana \\
Aks6 & Saya kitar semula barangan kaca. & 338 & 2.97 & 0.99 & Sederhana \\
Aks7 & Saya kitar semula tin aluminium. & 338 & 3.15 & 0.95 & Sederhana \\
Aks8 & Saya kitar semula barangan logam. & 338 & 2.95 & 0.97 & Sederhana \\
\hline & \multicolumn{1}{c}{ Keseluruhan Amalan Kitar Semula } & 3.02 & 0.96 & Sederhana \\
\hline
\end{tabular}

Petunjuk penetapan tahap: min 1.00-2.50 rendah, min 2.51-3.50 sederhana, min 3.51-5.00 tinggi

Jadual 2 menunjukkan keputusan ujian Korelasi Pearson antara pembolehubah sikap alam sekitar, keprihatinan alam sekitar dengan amalan kitar semula. Dapatan menunjukkan wujud hubungan yang signifikan dan positif antara sikap alam sekitar dengan amalan kitar semula $(\mathrm{r}=0.80$, sig=0.00). Dapatan juga menunjukkan wujud hubungan signifikan dan positif antara keprihatinan alam sekitar dengan amalan kitar semula $(\mathrm{r}=0.82$, sig=0.00).Ha1 dan $\mathrm{Ha} 2$ diterima.

Jadual 2 Hubungan antara sikap alam sekitar, keprihatinan alam sekitar dengan amalan kitar semula

\begin{tabular}{llcc}
\hline & & Amalan Kitar Semula & Sikap Alam Sekitar \\
\hline Amalan Kitar Semula & Pearson Correlation & 1 & $0.80 * *$ \\
& Sig. (2-Hala) & 338 & 0.00 \\
& $\mathrm{~N}$ & Amalan Kitar Semula & Keprihatinan Alam Sekitar \\
\hline \multirow{2}{*}{ Amalan Kitar Semula } & Pearson Correlation & 1 & $0.82^{* * *}$ \\
& Sig. (2-Hala) & 338 & 0.00 \\
& $\mathrm{~N}$ & & 338 \\
\hline **Korelasi signifikan pada tahap 0.01 (2 Hala) & &
\end{tabular}

Sumbangan pembolehubah tidak bersandar sikap alam sekitar dan keprihatinan alam sekitar kepada pembolehubah bersandar amalan kitar semula dihuraikan dengan menggunakan kaedah analisis regresi liner pelbagai langkah demi langkah dijalankan. Jadual 3 memaparkan ringkasan model sumbangan sikap alam sekitar dan keprihatinan alam sekitar terhadap amalan kitar semula.

Jadual 3 Ringkasan model amalan kitar semula

\begin{tabular}{ccccc}
\hline Model & R & R Square & $\begin{array}{c}\text { Adjusted R Square } \\
\text { Std. Error of the } \\
\text { Estimate }\end{array}$ \\
\hline $\mathbf{1}$ & $.828^{\mathrm{a}}$ & .686 & .685 & .39306 \\
$\mathbf{2}$ & $.850^{\mathrm{b}}$ & .722 & .720 & .37037 \\
\hline
\end{tabular}

a. Peramal: (Constant), Keprihatinan Alam Sekitar

beramal: (Constant), Keprihatinan Alam Sekitar, Sikap Alam Sekitar

Pembolehubah Bersandar: Amalan Kitar Semula

Daripada Jadual 3, didapati keprihatinan alam sekitar menyumbang 68.6 peratus kepada amalan kitar semula. Apabila digabungkan sumbangan keprihatinan alam sekitar dan sikap alam sekitar, sumbangan keseluruhan meningkat kepada 72.2 peratus. Oleh itu boleh dirumuskan bahawa keprihatinan alam sekitar dan sikap alam sekitar menyumbang sebanyak 72.2 peratus kepada amalan kitar semula. Oleh itu $\mathrm{Ha} 3$ dan $\mathrm{Ha} 4$ gagal ditolak.

Rumusan sumbangan pembolehubah sikap alam sekitar dan keprihatinan alam sekitar terhadap amalan kitar semula diringkaskan dalam Jadual 4 berikut. 
Jadual 4 Pekali regresi amalan kitar semula

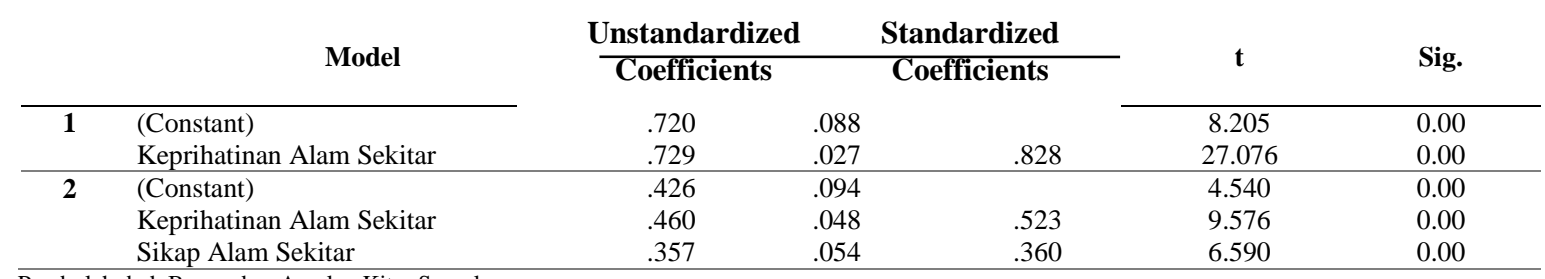

Pembolehubah Bersandar: Amalan Kitar Semula.

Daripada Jadual 4 tersebut, kajian ini membuat persamaan regresi untuk meramalkan amalan kitar semula seperti berikut,

Amalan Kitar Semula, $Y=0.426+0.460_{\mathrm{x} 1}+0.357_{\mathrm{x} 2}$

Daripada persamaan tersebut $\mathrm{X}_{1}$ adalah keprihatinan alam sekitar dan $\mathrm{X}_{2}$ adalah sikap alam sekitar. Daripada model pekali regresi dan persamaan tersebut, dapatan akhir kajian ditunjukkan dalam analisis path seperti Rajah 2 yang berikut:

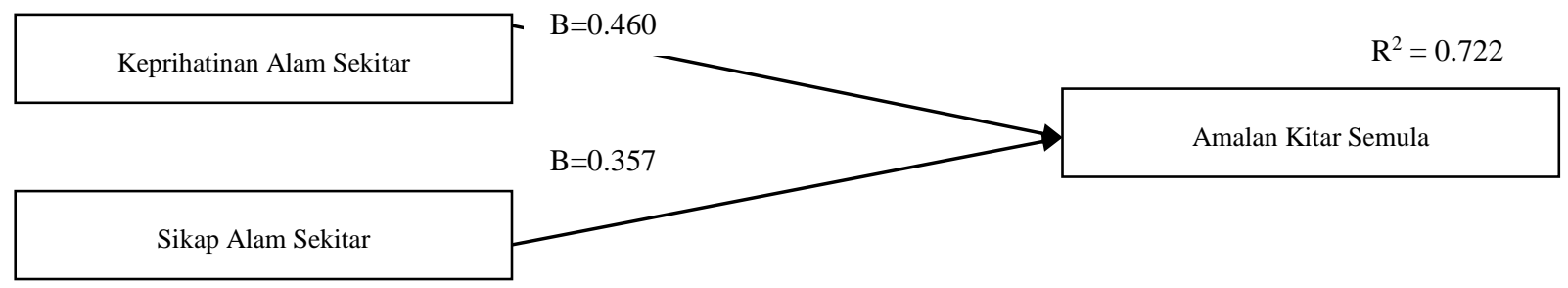

Rajah 2 Model akhir kajian amalan kitar semula

\subsection{RUMUSAN DAN CADANGAN}

Dapatan kajian menunjukkan wujud hubungan yang positif antara sikap alam sekitar, keprihatinan alam sekitar amalan kitar semula. Dapatan juga menunjukkan bahawa sikap alam sekitar dan keprihatinan alam sekitar adalah peramal yang signifikan kepada amalan kitar semula. Dapatan kajian yang dipaparkan dalam model akhir menunjukkan bahawa teori tingkahlaku terancang yang diaplikasikan dalam kajian ini menggambarkan model yang agak baik dengan $\mathrm{R}^{2}=0.722$. Dapatan ini adalah selari dengan kajian Chan (1998) di Hong Kong mendapati teori tingkahlaku terancang meramalkan niat bertingkahlaku dan tingkahlaku kitar semula.

Kesedaran menjaga alam sekitar responden adalah positif berkaitan dengan sikap. Oleh itu tahap keprihatinan dan kesedaran alam sekitar yang berkaitan adalah pembolehubah potensi yang menyumbang kepada amalan kitar semula. Sidique, Joshi dan Lupi (2010) mendapati komunikasi dan pendidikan boleh meningkatkan kesedaran mengenai sikap kitar semula dan berkesan dalam menggalakkan aktiviti kitar semula. Bratt (1999), Saphores, Nixon, Ogunseitan dan Shapiro (2006), dan Kataria dan Larsen (2009) juga mendapati bahawa kempen awam dan pendidikan adalah elemen-elemen penting dalam meningkatkan pengetahuan responden yang membawa kepada amalan kitar semula. Norma-norma sosial telah didapati memberi kesan besar ke atas amalan kitar semula, selaras dengan penemuan awal daripada kajian oleh melakukan Do Valle, Reis, Menezes dan Rebelo (2004), Shaw (2008) serta Andersson dan Von Borgstede (2010). Menurut Hofstede dan Bon (1988) norma sosial memainkan peranan penting dalam mempengaruhi tingkahlaku manusia. Sikap didapati mempunyai kesan yang besar tetapi agak kecil ke atas amalan kitar semula di Malaysia.

Dapatan kajian menunjukkan terdapat hubungan positif yang signifikan antara sikap alam sekitar $(\mathrm{r}=0.80$, sig=0.00) dan keprihatinan alam sekitar $(\mathrm{r}=0.82$, sig=0.00) dengan amalan kitar semula. Dapatan kajian ini adalah selari dengan dapatan kajian oleh Dispoto (1997), Ling-Yee (1997), Rahbar dan Nabsiah (2010) dan Saripah dan Mohd Shukri (2012). Kajian mereka mendapati sikap alam sekitar mempunyai hubungan yang positif dengan amalan kitar semula. Dalam konteks antara amalan kitar semula dengan keprihatinan kitar semula dapatan kajian ini selari dengan dapatan kajian oleh Chan dan Lau (2000), Md. Nor dan Sunarti (2000), Aini, Fakhru'l-Razi, Laily dan Jariah (2003), Mohamad Fazli dan Yong (2006), Ramayah, Lee dan Mohamad (2010) dan Lizawati Aman, Amran dan Zuhal (2012). Kajian mereka mendapati keprihatinan alam sekitar berhubungan positif dengan amalan kitar semula.

Dapatan kajian menunjukkan pembolehubah keprihatinan alam sekitar adalah peramal yang signifikan kepada amalan kitar semula $(\mathrm{B}=0.460$, sig=0.00), sikap alam sekitar $(\mathrm{B}=0.357$, sig=0.00). Dapatan kajian ini juga menunjukkan keprihatinan alam sekitar dan sikap alam sekitar menyumbang 72.2 peratus kepada amalan kitar semula. Peratusan sumbangan tersebut adalah sangat baik dan boleh diterima (Lea, 1997).

Bagi sumbangan keprihatinan alam sekitar terhadap amalan kitar semula, dapatan ini adalah selari dengan kajian oleh Minton dan Rose (1997) serta Mohamad Fazli dan Yong (2006). Dapatan kajian mereka menunjukkan keprihatinan alam sekitar meramal dan menyumbang secara positif terhadap amalan kitar semula. Bagi kajian ini fungsi yang menyumbang adalah 'kita tidak berusaha 
secukupnya untuk melindungi sumber semula jadi yang terhad,' 'sumber semulajadi mesti dilindungi walaupun manusia tidak dapat sesuatu produk', 'terlalu banyak aduan telah dibuat tentang pencemaran air,' 'membayar harga yang lebih tinggi untuk produk yang mencemarkan alam sekitar,' 'bekas yang tidak boleh dikitar semula patut dikenakan cukai,' 'pengeluar diwajibkan untuk menggunakan bahan kitar semula dalam operasi mereka' dan 'pengiklanan komersial diwajibkan untuk memberitahu keburukan sesuatu produk itu terhadap alam sekitar.'

Bagi sumbangan sikap alam sekitar terhadap amalan kitar semula, hasil dapatan juga adalah selari dengan hasil kajian Bohlen, et. al., (1993), Nik Abdul Rashid (2009) serta Rahbar dan Nabsiah (2010). Fungsi yang menyumbang dalam kajian ini adalah 'membuat sumbangan untuk perlindungan alam sekitar boleh memberi kesan yang positif,' 'kita perlu melindungi alam sekitar untuk generasi akan datang,' 'kita berupaya untuk membantu memperlahankan kemerosotan alam sekitar,' 'di peringkat antarabangsa perlindungan alam sekitar mestilah diambil segera untuk menghentikan kemerosotan alam sekitar,' 'alam sekitar adalah isu yang paling penting dalam masyarakat' dan 'firma swasta perlu berfikir mengenai perlindungan alam sekitar terlebih dahulu sebelum memikirkan keuntungan.'

Dapatan kajian ini berjaya mengenal pasti faktor-faktor dalaman yang mempengaruhi amalan kitar semula. Walaupun begitu, kajian ini hanya dijalankan di peringkat Negeri Terengganu sahaja. Dapatan kajian ini tidak menggambarkan situasi dan amalan kitar semula dalam konteks Malaysia secara menyeluruh. Bagi memantapkan lagi kajian mengenai amalan kitar semula, dicadangkan kajian lanjut dijalankan dengan menjadikan generasi Y Malaysia sebagai populasi kajian. Dapatan kajian tersebut nanti akan lebih mantap dari sudut generalisasi yang lebih menyeluruh.

Pembangunan insan yang berdasarkan kepada kehidupan yang berteraskan nilai-nilai agama, bertanggungjawab dengan alam sekitar dan membangun alam sekitar secara terancang perlu diberi penekanan yang bersungguh-sungguh. Dicadangkan juga supaya satu kajian lanjutan dijalankan dengan mengambil kira aspek keagamaan sebagai salah satu faktor yang mempengaruhi amalan kitar semula. Dapatan kajian tersebut nanti dapat membuat penambahbaikan kepada teori sebagai sesuatu penemuan baharu kajian.

Hubungan antara masyarakat dengan alam sekitar sebenarnya boleh diharmonikan melalui beberapa pendekatan yang antaranya dengan mempraktikkan gaya hidup yang lestari. Amalan dan gaya hidup yang lestari menuntut agar setiap anggota masyarakat menjalinkan hubungan yang harmoni dengan alam sekitar bagi mengelakkan timbulnya pelbagai kesan negatif terhadap persekitaran dan kesihatan.

\section{Rujukan}

A. H. Lizawati Aman, Amran H. dan Zuhal H. (2012). The Influence of Environmental Knowledge and Concern on Green Purchase Intention the Role of Attitude as a Mediating Variable. British Journal of Arts and Social Sciences. 7 (II), 145-167.

Abu Hanifah, Y., Mohd Rafi, Y. dan Nik Mazlan, N. H. (2012). Cabaran Usahawan Bumiputera Kitar Semula: Satu Tinjauan di Kelantan dan Terengganu. Seminar Kebangsaan Kolej Komuniti. PWTC, Kuala Lumpur. Dicapai melalui http://umkeprints.umk.edu.my/1116.

Aini, M. S., Fakhru'l-Razi A., Laily H. P. dan M. Jariah. (2003). Environmental Concerns, Knowledge And Practices Gap Among Malaysian Teacher. International Journal of Sistainability in Higher Education. 4 (4), 305-313.

Ajzen, I. (1991). The Theory of Planned Behavior. Organizational Behavior and Human Decision Processes. 50 (2), 179-211.

Ajzen, I. dan Fishbein, M. (1980). Understanding Attitudes And Predicting Social Behavior. Prentice-Hall, Englewood Cliffs, New Jersey.

Andersson, M., Von Borgstede, C. (2010). Differential Determinants of Low-Cost and High-Cost Recycling. Journal of Environmental Psychology, 10, $402-408$

Arcury, T. A. dan Christianson, E. H. (1990). Environmental Worldview in Response to Environmental Problems: Kentucky 1984 and 1988 Compared. Environment Behavior. 22 (3), 387-407.

Azizan, R. (2010). Membudayakan Minda Lestari dalam Pengurusan Alam Sekitar. (Diedit oleh Tuan Sidek Tuan Muda). Penerbit Universiti Malaysia Pahang. Gambang, Kuantan.

Bejou, D. dan Thorne, D. (1991). Exploring the Differences Between Recyclers And Non-Recyclers: The Roles Of Demographics And Personal Factors. Proceeding of the Southern Marketing Association Conference. 91, 110-115.

Bohlen, G., Schlegelmilch, B. B., dan Diamantopoulos, A. (1993). Measuring Ecological Concern: A Multi-Construct Perspective. Journal of Marketing Management. 9 (4), 415-430

Bradley, C. J., Waliczek, T. M. dan Zajicek, J. M. (1999). Relationship Between Environmental Knowledge and Environmental Attitude of High School Students. The Journal of Environmental Education. 30 (3), 17-21.

Bratt, c. (1999). The Impact of Norms and Assumed Consequences on Recycling Behaviour. Journal of Environment and Behaviour, 31, 630-656.

Chan, K. (1998). Mass Communication and Pro-Environmental Behaviour: Waste Recycling in Hong Kong. Journal of Environmental Management, 52, 317-325.

Chan, R. Y. K., dan Lau, L. B. Y. (2000). Antecedents of Green Purchases: A Survey in China. Journal of Consumer Marketing. 17 (4), 338-357.

Cheku, N. H. (2014). Faktor Yang Mempengaruhi Amalan Kitar Semula Dalam Kalangan Generasi Y Di Ipt Negeri Terengganu. Universiti Malaysia Terengganu, Tesis Sarjana.

Daigle, J. J., Hrubes, D. dan Ajzen, I. (2002). A Comparative Study Of Beliefs, Attitudes, And Values Among Hunters, Wildlife Viewers, And Other Outdoor Recreationists. Human Dimension of Wildlife. 7 (1), 1-19.

Dispoto, R. G. (1997). Interrelationship among Measures of Environmental Activity, Emotionality and Knowledge. Educational and Psychological Measurement. 37(4), 451-459.

Do Valle, P. O., Reis, E., Menezes, J., dan Rebelo, E. (2004). Behavioural Determinants of House-Hold Recycling Participation: The Portugese Case. Journal of Environment and Behaviour, 36, 505-540.

Durning, A. T. (1992). How Much Is Enough? The Consumer Society And The Future Of The Earth. World Watch Institute Norton and Company. New York.

Eagles, P. F. dan Demare, R. (1999). Factors Influencing Children' Environmental Attitudes. The Journal of Environmental Education. 30 (4), $33-37$.

Evison, T. dan Read, A.D. (2001). Local Authority Recycling and Waste Awareness Publicity/Promotion in United Kingdom. Journal of Resource Conservation and Recycling. 32 (3), 275-291.

Follows, S. dan Jobber, D. (2000). Environmentally Responsible Purchase Behavior: A Test Of A Consumer Model. European Journal of Marketing, 34 (5), $723-746$.

Gill, L. A., Crosby, J. R. dan Taylor, J. D. (1986). Ecological Concern, Attitudes, and Social Norms in Voting Behavior. Public Opinion Quarterly. 50 (4), $537-554$.

Hofstede, G., dan Bond, M. H., (1988). The Confucian Connection: From Cultural Roots to Economic Growth. Organizational Dynamics, 16, 4-21.

Holmes, R. III (2006). Environmental and Religion/Science. The Oxford Handbook of Religion and Science. (Diedit oleh Philip Clayton dan Zachary simpson). Oxford University Press. United States, Amerika Syarikat.

Jabatan Alam Sekitar Malaysia (1998). Laporan Kualiti Alam Sekeliling. Kementerian Teknologi dan Alam Sekitar Malaysia, Kuala Lumpur.

Jamilah, A., Hasrina, M., Hamidah, A. H. dan Juliana, A. W. (2011). Pengetahuan, Sikap dan Amalan Masyarakat Malaysia terhadap Isu Alam Sekitar. Akademika Jurnal. $81(3), 103-115$

Johnson Controls Global WorkPlace Solutions (2010). Global WorkPlace Innovation: Generation Y and the Workplace Annual Report 2010. Intellectual Property Johnson Controls, Haworth and iDEA, London, UK. 
Kazemi, B. M. (1996). Disposal and Recycle of Solid Waste, Biogas Composting. 1st ed. Publication of Mashad Ferdousy University, Iran.

Knapp, C. E. (1999). In Accord With Nature: Helping Students Form An Environmentalethic Using Outdoor Experience And Reflection. West Virginia: ERIC Clearinghouse on Rural Education and Small Schools.

Krejcie, R. V dan Morgan, D. W. (1970). Determining Sampel Size For Research Activities. Educational and Psychological Measurement. 30 (3), 607-610.

Latifah, A. M. (2011). Aplikasi Sistem Pintar dalam Pengurusan Sisa Pepejal. Dewan Bahasa dan Pustaka. Kuala Lumpur.

Lau, T. C. (2010). Towards Socially Responsible Consumption: An Evaluation of Religiosity and Money Ethics. International Journal of Trade, Economics and Finance, 1 (1), 32-35.

Lea, S. (1997). Logistic Regression And Discriminant Analysis. http://www.ex.ac.uk/ SEGLea/multvar2/discologi.html

Ling-Yee, L. (1997). Effect of Collectivist Orientation and Ecological Attitude on Actual Environmental Commitment: The Moderating Role of Consumer Demographic and Product Involvement. Journal of International Consumer Marketing, 9 (4), 31 - 54.

McCarty, J. A. dan Shrum, L. J. (1994). The Recycling of Solid Waste: Personal Values, Value Orientations and Attitudes about Recycling as Antecedents of Recycling Behavior. Journal of Business Research. 30 (1), 53-62.

Md. Nor, O. dan Sunarti, M. U. (2000). Kesedaran Terhadap Alam Sekitar: Kajian Perbandingan antara Pengguna Melayu dan Cina Bandar. Malaysian Journal of Consumer and Family Economics. 3, 42-50.

Minton, A. P. dan R. L. Rose (1997). The Effects Of Environmental Concern On Environmentally Friendly Consumer Behavior. Journal of Busines Research, 40 (1), 37-48.

Mittelstaedt, R., Sanker, L. dan VanderVeer, B. (1999). Impact of a Week-Long Experiential Education Program on Environmental Attitude and Awareness. Journal of Experiential Education, 22 (3), 138-148.

Mohamad Fazli, S. dan Yong, T. Y. (2006). Tahap Keprihatinan Alam Sekitar dan Amalan Kepenggunaan Hijau Pengguna di Petaling Jaya, Selangor. Pertanika: Journal of Social Science and Human, 14 (2), 95-109.

Mohd Nasir H., Rakmi A. R., Theng L. C., Zulina Z. dan Muhamad A. (2000). Waste Recycling in Malaysia: Problems and Prospects. Waste Management Resources, 18(4), 320-328.

Nik Abdul Rashid, N. R. (2009). Employee Involvement In EMS/ISO 14001 And Its Spillover Effect In Consumer Environmentally Responsible Behavior. Universiti Sains Malaysia, Disertasi Phd.

Paco, A. F., Raposo, M. L., dan Filho, W. L. (2009). Identifying The Green Consumer: A Segmentation Study. Journal of Targeting, Measurement and Analysis for Marketing, 17 (1), 17-25.

Payam, E. S. (1995). Effort to Protection of Natural Resources, 2nd issue, Isfahan Industrial University, Iran.

Perbadanan Pengurusan Sisa Pepejal dan Pembersihan Awam (2011). Dicapai pada 25 Mac 2012, melalui http://www.sisa.my/sisamy/index PROGRAM PENGURUSA SISA PEPEJAL.pdf

Rabinson, W. D. (1986). The Solid Waste Hand Book: A Practical Guide. John Willey, New York, USA

Rahbar, E. Dan Nabsiah, A. W. (2010). The Malaysian Consumer and The Environment: Purchase Behavior. Global Business and Management Research, 2 (4), $323-$ 336.

Ramayah, T., Lee, J. W. C. dan Mohamad, O. (2010). Green Product Purchase Intention: Some Insights From A Developing Country. Resources, Conservation and Recycling, 54, 1419-1427.

Robinson, G. M. dan Read A. D. (2005). Recycling Behaviour in a London Borough: Results from Large-Scale Household Surveys. International Journal of Resource, Conversation and Recycle, 45 (1), 70-83.

Samuelson, C. D. dan Biek, M. (1991). Attitudes Towards Energy-Conservation: A Confirmatory Factor Analysis. Journal of Applied Social Psychology, 12 (7), 549568 .

Saphores, J. M., Nixon, H., Ogunseitan, O. A., dan Shapiro, A. A. (2006). Household Willingness to Recycle Electronic Waste: An Application to California. Journal of Environment and Behaviour, 38, 183-208

Saripah, A. L. dan Mohd Shukri, O. (2012). Recycling Behaviour In Tioman Island: A Case Study. Procedia-Social and Behavioral Sciences, $36,707-715$.

Sharifah Azizah, H., Laily, P. dan Nurizan Y. (2005). Towards sustainable consumption: an examination of environmental knowledge among Malaysians. International Journal of Consumer Studies, 29 (5), 426-436.

Shaw, P.J. (2008). Nearest Neighbour Effects in Kerbside Household Waste Recycling. Journal of Resources, Conservation and Recycling, 52, 775-784

Sidique, S. F., Joshi, S. V. dan Lupi, F. (2010). Factors Influencing The Rate of Recycling: An Analysis of Minnesota Counties. Resources, Conservation and Recycling, 54 (4), 242-249.

Webb, D. J., Mohr, L. A. dan Harris, K. E. (2008). A Re-Examination of Socially Responsible Consumption and Its Measurement. Journal of Business Research, 61 (2), 91-98.

Wilson, D. C. (1981). Waste Management: Planning, Evaluation, Technologies. Oxford University Press. Oxford, UK.

World Bank (1999). What A Waste-Solid Waste Management in Asia. Urban and Local Government Working Papers. The International Bank for Reconstruction and Development/The World Bank, 1818 H. Street, N. W. Washington, D.C. 